\title{
Rancang Bangun Aplikasi "Kmois" Kamus Bahasa Indonesia Moi Berbasis Android
}

\author{
Trio Nurdianto ${ }^{1}$, Novita Wulandari ${ }^{2}$, Firman $^{3}$ \\ Prodi Pendidikan Teknologi Informasi \\ Universitas Pendidikan Muhammadiyah Sorong \\ trionurdiantosenju@gmail.com ${ }^{1}$, novitawulandariumar@gmail.com² \\ firmantajdiduliman@gmail.com ${ }^{3}$
}

\begin{abstract}
Abstrak: Bahasa Moi Merupakan Bahasa suku asli masyarakat kabupaten sorong yang perlu dilestarikan dan dapat mudah dipelajari masyarakat Kabupaten Sorong. Tujuan penelitian ini adalah Menghasilkan Aplikasi Kmois berbasis Android dan menghasilkan cara penggunaan Aplikasi Kmois berbasis android. Bentuk penelitian ini menggunakan motode Research and Development (R\&D) dan menggunakan model Prototyping dalam pengembangan Aplikasi. Berdasarkan hasil penelitian yang telah dilakukan di dapatkan hasil berupa aplikasi Kmois yang dapat berjalan di sistem android dan petunjuk peggunaan sebagai pedoman penggunaan aplikasi yang keduanya telah melalui tahap ujicoba kepada 31 orang responden dengan memperoleh presentase nilai $84 \%$ untuk aspek tampilan dan $88 \%$ untuk aspek penggunaan. Dengan demikian dapat disimpulkan bahwa rancang bangun aplikasi Kmois berbasis Android dan petunjuk penggunaan Aplikasi telah berhasil terselesaikan dan dapat di gunakan dengan baik serta memperoleh penilaian sangat baik oleh pengguna.
\end{abstract}

Kata Kunci: Android; Aplikasi; Kamus.

\begin{abstract}
Moi Language is the language of the indigenous people of the Sorong Regency community that needs to be preserved and can be easily learned by the people of Sorong Regency. The purpose of this research is to produce an Android-based Kmois application and to produce a way to use the Android-based Kmois application. This form of research uses the Research and Development $(R \& D)$ method and uses the Prototyping model in application development. Based on the results of the research that has been carried out, the results are in the form of the Kmois application that can run on the Android system and instructions for use as a guideline for using the application, both of which have gone through the trial stage to 31 respondents by obtaining a percentage value of $84 \%$ for the display aspect and $88 \%$ for the use aspect. . Thus it can be concluded that the design of the Android-based Kmois application and the instructions for using the application have been successfully completed and can be used properly and have received very good ratings by users.
\end{abstract}

Keywords: Android; Application; Dictionary.

\section{Pendahuluan}

Bahasa Moi perlu di lestarikan oleh setiap warga di kabupaten sorong sesuai dengan Peraturan Daerah (PERDA) Kabupaten Sorong nomor 10 tahun 2017 tentang pengakuan dan perlindungan masyarakat hukum adat Moi di Kabupaten Sorong. Bahasa Moi sendiri sudah mulai di tinggalkan oleh masyarakat di karenakan perkembangan zaman yang sangat pesat. Penduduk asli Moi yang memiliki jumlah cukup sedikit memunculkan kekhawatiran mengenai pelestarian bahasa Moi itu sendiri, solusi terbaiknya adalah membuat kamus bahasa Moi sehingga dapat di pelajari oleh seluruh kalangan tidak hanya oleh masyarakat suku Moi. Pemerintah Kabupaten Sorong sendiri telah mengeluarkan kewajiban bagi aparatur daerah untuk menggunakan bahasa Moi di setiap hari kamis pada jam kantor, dengan adanya kamus 
Moi setiap masyarakat yang tinggal di Kabupaten Sorong dapat belajar menggunakan bahasa Moi dengan mudah.

Pada era digital seperti saat ini penggunaan kamus dalam bentuk buku di nilai kurang efektif di kalangan masyarakat karena mobilitas yang kurang baik dan tidak dapat di gunakan kapan saja saat di perlukan, masyarakat akan lebih mudah menggunakannya jika dapat di akses pada smatfone mereka karna di anggap efisien digunakan kapan saja dan di mana saja. (Haris and Pardiansyah, 2018)penelitiannya tentang Aplikasi Android Kamus Bahasa IndonesiaSasak. Penelitian yang di lakukan dilatarbelakangi mulai memudarnya bahasa sasak di kalangan masyarakat generasi saat ini. Aplikasi android yang di buat dapat berjalan pada versi android minimal versi Froyo 2.2 dan maximal versi Jelly Bean 4.2. Perbedaan dengan penelitian ini adalah versi minimal Android yang di pakai dan Bahasa yang di terjemah juga berjumlah 3 bahasa yakni Bahasa Sesak biasa - Indonesia, Sesak halus- Indonesia dan Sesak Kasar-Indonesia.(Wati and Ernawati, 2018) penelitiannya tentang Perancangan Aplikasi Kamus Bahasa Jawa-Indonesia Berbasis Android. Aplikasi yang di buat menggunakan perancangan sistem dengan model Waterfall dengan menggunakan software Eclipse sebagai produksi aplikasi. Penelitian ini bertujuan untuk memudahkan pengguna dalam meningkatkan pengetahuan mengenai kosakata jawa yang terbilang sulit karena memiliki beberapa tingkatan bahasa yakni yaitu bahasa jawa kasar dan bahasa jawa halus atau dikenal dengan istilah ngoko, kromo dan kromo inggil. Perbedaan dengan Penelitian yang di lakukan penulis adalah model pengembangan program yang di gunakan menggunakan waterfall dan softwere pemngembangan program yang di gunakan Eclipse sedangkan penulis menggunakan model Prototyping dan aplikasi Android Studio.

(Sofya, Esabella and -, 2017) penelitiannya tentang Rancang Bangun Aplikasi Kamus Sumbawa Berbasis Android. Penelitiannya adalah merancang dan membangun aplikasi kamus yang memuat kosakata bahasa sumbawa beserta contoh kalimat, dan dalam membangun aplikasi tersebut peneliti menggunakan Android Studio 1.5 dan database SQlite. Penelitian ini di lakukan bertujuan untuk memudahkan masyarakat luar berinteraksi dengan masyarakat asli sumbawa, serta untuk mengefektifkan dalam mencari kosa kata sumbawa tanpa perlu mencari pada kamus yang berbentuk buku yang relatif tebal. Perbedaan dengan penelitian yang dilakukan penulis adalah pada penerjemahannya pada penelitian Sofya Bahasa yang di terjemah hanya satu yakni dari Bahasa Sumbawa ke Indonesia namun menyertakan Contoh kalimat beserta artinya sedangkan yang penulis buat hanya mengartikan kosakata dan mengartikan 2 bahasa yakni Moi-Indonesia dan Indonesia-Moi.

\section{Metode Penelitian}

Model Penelitian atau pengembangan yang di gunakan adalah (research and development/ R\&D). Penelitian dan Pengembangan atau Research and Development (R\&D) adalah suatu proses atau langkah - langkah untuk mengembangkan suatu produk baru atau menyempurnakan produk yang telah ada sehingga dapat dipertanggungjawabkan. Produk tersebut tidak selalu berbentuk hardware software tetapi program komputer untuk pengelolahan data, pembelajaran di kelas, perpustakaan atau laboratorium, pelatihan, bimbingan, evaluasi dan manajemen (Winarni, 2018).

Tempat penelitian akan dilakukan di kabupaten sorong tepatnya di LMA (Lembaga Masyarakat Adat) MalaMoi dan waktu pelaksanaan penelitian di mulai pada Februaru 2020. Subjek penelitian adalah orang yang dijadikan sebagai sumber data atau sumber informasi bagi peneliti dalam menyelesaikan penelitiannya. Subjek penelitian dalam rancang bangun aplikasi KMOIS berbasis android adalah masyarakat Pendatang yang tinggal di Kabupaten Sorong.

Teknik Pengumpulan data yang digunakan adalah studi pustaka, wawancara dan angket/Kuisoner. (Studi pustaka) merupakan kegiatan yang berkaitan dengan pengkajian 
terhadap sumber-sumber referensi yang berkaitan tentang landasan teori konseptual dan praktis permasalahan. Studi pustaka pada penelitian ini dilakukan pada buku kamus Moi karangan Dr. Stepanus Malak, M.Si. dan jurnal-jurnal yang berkaitan dengan penelitian ini. (Wawancara) di lakukan guna mengumpulkan data-data yang di butuhkan serta memperoleh keterangan untuk tujuan penelitian dengan cara tanya jawab tatap muka maupun teknologi dengan narasumber. Narasumber yang diambil dalam pembuatan aplikasi adalah ketua Lembaga Masyarakat Adat (LMA) Malamoi Kabupaten Sorong. (Kuisioner) merupakan Teknik pengumpulan data yang dilakukan dengan memberi seperangkat pertanyaan atau pernyataan tertulis kepada responden untuk dijawabnya. Kuisoner merupakan Teknik analisis data yang efisien apabila peneliti mengetahui dengan pasti variable yang akan diukur dan tahu apa yang bias didapatkan dari responden. Angket akan diberikan kepada validator ahli serta pengguna dalam ujicoba kelompok besar untuk melihat penilaian tentang aplikasi yang telah dibuat.

Teknik analisis data pada penelitian ini menggunakan teknik analisis data deskriptif, dalam penelitian ini peneliti melakukan analisis terhadap kelayakan sistem dengan mengunakan perhitungan sebagai berikut. Presentase Kelayakan $=\frac{\text { Nilai Total }}{\text { Nilai Maksimum }} X 100 \%$

Dengan menggunakan perhitungan tersebut dapat di hasilkan nilai sebagai pengukuran apakah layak atau tidak layak aplikasi yang telah di buat.

\section{Hasil dan Pembahasan}

Hasil pengembangan aplikasi kmois dengan menggunakan aplikasi Android Studio dan database Sqlite telah menghasilkan aplikasi yang dapat berjalan sesuai dengan rancangan aplikasi yang telah dibuat, aplikasi Kmois memiliki 4 navigasi pada menu utamanya, yaitu: Indonesia-Moi, Moi-Indonesia, Tentang dan keluar. Petunjuk Penggunaan aplikasi Kmois dapat di lihat menggunakan 2 cara yakni dengan melihat pada menu bantuan yang terdapat di option menu pada aplikasi Kmois dan pada video yang telah tersedia di youtube. Petunjuk penggunaan aplikasi Kmois menerangkan tentang cara memperoleh terjemahan kosakata yang dicari berupa arti Bahasa Moi maupun Bahasa Indonesia.

Pengujian blackbox di lakukan memiliki beberapa komponen yang akan diujikan. Komponen yang di ujikan adalah penginstalan, layout menu utama, layout menu IndonesiaMoi, layout menu Moi-Indonesia, layout menu tentang dan layout menu keluar. Tabel 1 Rangkuman hasil pengujian blackbox.

Tabel 1. Pengujian blackbox

\begin{tabular}{llll}
\hline No. & Rancangan proses & Hasil yang diharapkan & Hasil Pengujian \\
\hline 1. & Instalasi Aplikasi & $\begin{array}{l}\text { Aplikasi dapat terinstall pada } \\
\text { Android dengan versi 5.0 } \\
\text { keatas }\end{array}$ & Sesuai \\
& & Layout Menu Utama & \\
\hline 2. & Masuk Aplikasi & $\begin{array}{l}\text { Masuk kedalam aplikasi } \\
\text { yang telah terinstall }\end{array}$ & Sesuai \\
3. & Klik Menu & $\begin{array}{l}\text { Menampilkan Tampilan } \\
\text { menu Indonesia-Moi }\end{array}$ & Sesuai \\
& Indonesia-Moi & $\begin{array}{l}\text { Menampilkan Tampilan } \\
\text { 4. }\end{array}$ & Klik Menu Moi- \\
& Indonesia & Menu Moi-Indonesia & Sesuai \\
\hline
\end{tabular}




\begin{tabular}{lrlr}
\hline 5. & Klik Menu Tentang & $\begin{array}{l}\text { Menampilkan Tampilan } \\
\text { Menu Tentan }\end{array}$ & Sesuai \\
6. Klik Menu Keluar & $\begin{array}{l}\text { Menampilkan } \\
\text { Pemberitahuan apakah anda } \\
\text { ingin keluar aplikasi? }\end{array}$ & Sesuai \\
7. Klil panel kembali & $\begin{array}{l}\text { Menampilkan } \\
\text { Pemberitahuan apakah anda } \\
\text { ingin keluar aplikasi? }\end{array}$ & Sesuai \\
& &
\end{tabular}

\begin{tabular}{|c|c|c|c|}
\hline \multicolumn{4}{|c|}{ Layout Menu Indonesia-Moi } \\
\hline 8. & Input Kosakata & $\begin{array}{l}\text { Menampilkan daftar kata } \\
\text { yang tersedia sesuai dengan } \\
\text { kata yang di inputkan }\end{array}$ & Sesua \\
\hline 9. & $\begin{array}{l}\text { Klik button } \\
\text { terjemahkan }\end{array}$ & $\begin{array}{l}\text { Menampilkan arti kosakata } \\
\text { Moi apabila kosakata yang } \\
\text { di cari tersedia dan } \\
\text { menampilkan terjemahan } \\
\text { tidak di temukan apabila } \\
\text { kosakata tidak tersedia }\end{array}$ & Sesua \\
\hline
\end{tabular}

10. Klik panel kembali Kembali ke menu utama

Sesuai

\begin{tabular}{|c|c|c|c|}
\hline \multicolumn{4}{|c|}{ Layout Menu Indonesia-Moi } \\
\hline 11. & Input Kosakata & $\begin{array}{l}\text { Menampilkan daftar kata } \\
\text { yang tersedia sesuai dengan } \\
\text { kata yang di inputkan }\end{array}$ & Sesuai \\
\hline 12. & $\begin{array}{l}\text { Klik button } \\
\text { terjemahkan }\end{array}$ & $\begin{array}{l}\text { Menampilkan arti kosakata } \\
\text { Indonesia apabila kosakata } \\
\text { yang di cari tersedia dan } \\
\text { menampilkan terjemahan } \\
\text { tidak di temukan apabila } \\
\text { kosakata tidak tersedia }\end{array}$ & Sesuai \\
\hline 13. & Klik panel kembali & Kembali ke menu utama & Sesuai \\
\hline \multicolumn{4}{|c|}{ Layout Menu Tentang } \\
\hline 14. & Scrol Layar & $\begin{array}{l}\text { Layar dapat bergulir ke } \\
\text { bawah/keatas }\end{array}$ & Sesuai \\
\hline 15. & Klik panel kembali & Kembali ke menu utama & Sesuai \\
\hline
\end{tabular}

\section{Validasi Ahli}

Validasi ahli merupakan ujicoba terhadap aplikasi KMOIS untuk mengukur penilaian terhadap aplikasi yang di lakukan oleh ahli dalam bidangnya. Validasi aplikasi Kmois ini akan di berikan kepada 2 validator, validator I bertugas untuk menilai instrument dan validator II bertugas untuk menilai aplikasi itu sendiri. Dalam validasi terdapat 3 aspek yang dinilai, yaitu aspek program, aspek tampilan dan aspek penggunaan 


\section{Aspek Program}

Aspek program yang akan dinilai memiliki 2 indikator yaitu (1) Perangkat Lunak (Softwere) dan (2) Panduan Penggunaan. Pengujian dilakukan dengan menjalankan aplikasi dan menggunakan panduan aplikasi. Berdasarkan penilaian validator aspek program memperoleh rata-rata skor 3,6 atau prosentase $90 \%$ yang berarti memiliki kategori sangat baik.

\section{Aspek Tampilan}

Aspek tampilan yang akan di nilai memiliki 4 indikator yang terdiri dari beberapa poin, 4 indikator yang akan dinilai yaitu: (1) Keterbacaan Text, (2) Kualitas Gambar, (3) Keserasian Warna dan (4) Tombol. Penilaian aplikasi pada aspek tampilan akan di lakukan dengan membuka setiap fitur yang ada dalam aplikasi. Berdasarkan pengujian yang dilakukan validator memberikan nilai dengan rata-rata skor 3,4 dengan presentase $85 \%$ yang berarti memiliki kategori sangat baik.

\section{Aspek Penggunaan}

Aspek penggunaan yang akan di evaluasi memiliki 5 indikator yang setiap indikator memiliki poin-poin penilainannya. 4 indikator yang akan di evaluasi pada aspek penggunaan yaitu: (1) Kualitas Aplikasi, (2) Navigasi, (3) Penggunaan Aplikasi dan (4) Dampak bagi masyarakat. Berdasarkan penilaian yang dilakukan validator aspek pengguna mendapatkan rata-rata skor 3,7 atau dengan presentase $92 \%$ dengan demikian aspek pengguna mendapatkan penilaian sangat baik.

\section{Ujicoba Skala Besar}

Ujicoba skala besar di lakukan kepada masyarakat kabupaten sorong dengan target responden berjumlah 30 orang yang bersedia melakukan ujicoba aplikasi kmois pada link yang telah disebar melalui media sosial (whatsapp dan facebook). Ujicoba yang dilakukan akan mengukur 2 indikator yaitu (1) aspek tampilan dan (2) aspek penggunaan. Pengujian aplikasi dilakukan dengan mencoba seluruh proses input dan output serta melakukan percobaat terhadap seluruh fitur yang ada dalam aplikasi kmois. Dalam ujicoba skala besar ini peneliti memperoleh 31 responden yang yang merupakan masyarakat kota dan kabupaten sorong berbagai golongan.

\section{Aspek Tampilan}

Aspek tampilan yang akan dinilai oleh responden memiliki 10 poin penilaian yang meliputi penilaian mengenai seluruh aspek tampilan yaitu teks, gambar, tombol dan warna, yang dapat dilihat pada Tabel 2 .

Tabel 2 Ujicoba skala besar Aspek Tampilan

\begin{tabular}{clccc}
\hline No & \multicolumn{1}{c}{ Indikator } & Rerata & Presentase (\%) & Kesimpulan \\
\hline $\mathbf{1}$ & Ketepatan Warna Text & 3,4 & 85 & Sangat Baik \\
$\mathbf{2}$ & Ketepatan Jenis Huruf & 3,5 & 86 & Sangat Baik \\
$\mathbf{3}$ & Ketepatan Ukuran Huruf & 3,5 & 89 & Sangat Baik \\
$\mathbf{4}$ & Kejelasan Bentuk Gambar & 3,3 & 83 & Sangat Baik \\
$\mathbf{5}$ & Kejelasan Ukuran Gambar & 3,2 & 79 & Baik \\
$\mathbf{6}$ & Ketepatan Warna tema pada & 3,2 & 81 & Sangat Baik \\
\hline
\end{tabular}




\begin{tabular}{clccc}
\hline \multicolumn{2}{l}{ aplikasi } & & & \\
$\mathbf{7}$ & Keserasian warna tulisan & 3,3 & 83 & Sangat Baik \\
& dengan gambar & & & \\
$\mathbf{8}$ & Keserasian warna tombol & 3,2 & 80 & Baik \\
$\mathbf{9}$ & Penetapan tombol & 3,4 & 84 & Sangat Baik \\
$\mathbf{1 0}$ & Konsistensi tombol & 3,5 & 87 & Sangat Baik \\
\hline Keseluruhan indikator & $\mathbf{3 , 3}$ & $\mathbf{8 4}$ & Sangat Baik \\
\hline
\end{tabular}

Berdasarkan penilaian ujicoba kelompok besar pada aspek tampilan sesuai Tabel 2 dapat dilihat hampir seluruh poin memiliki predikat sangat baik dan hanya 2 poin yang memiliki predikat baik dengan rata-rata setiap poinnya bernilai 3,3 dengan presentase $84 \%$, dengan hasil yang telah didapat dapat disimpulkan bahwa aplikasi kmois pada aspek tampilan sangat baik dan layak digunakan.

\section{Aspek Penggunaan}

Aspek penggunaan memiliki 9 poin penilaian yang akan di nilai oleh responden, aspek penggunaan yang akan di nilai adalah aspek penggunaan aplikasi kmois serta aspek penggunaan panduan aplikasi kmois. Hasiil uji coba dapat dilihat pada Tabel 3.

Tabel 3. Ujicoba skala Besar Aspek Penggunaan

\begin{tabular}{clccc}
\hline No & \multicolumn{1}{c}{ Indikator } & Rerata & Presentase (\%) & Kesimpulan \\
\hline $\mathbf{1}$ & Mudah dipahami & 3,7 & 93 & Sangat Baik \\
$\mathbf{2}$ & Mudah digunakan & 3,8 & 94 & Sangat Baik \\
$\mathbf{3}$ & $\begin{array}{l}\text { Memudahkan dalam proses } \\
\text { mencari terjemahan kosakata }\end{array}$ & 3,5 & 88 & Sangat Baik \\
$\mathbf{4}$ & $\begin{array}{l}\text { Kemudahan dalam pindah } \\
\text { layout }\end{array}$ & 3,2 & 81 & Sangat Baik \\
$\mathbf{5}$ & $\begin{array}{l}\text { Kemudahan penggunaan } \\
\text { menu }\end{array}$ & 3,5 & 87 & Sangat Baik \\
$\mathbf{6} \quad \begin{array}{l}\text { Suport pada android versi 5.0 } \\
\text { keatas }\end{array}$ & 3,6 & 90 & Sangat Baik \\
$\mathbf{7} \quad \begin{array}{l}\text { Tidak terdapat kesalahan } \\
\text { (error) pada saat aplikasi }\end{array}$ & 3,2 & 81 & Sangat Baik \\
$\begin{array}{l}\text { dijalankan } \\
\text { Penginputan atau data yang } \\
\text { dimasukkan } \\
\text { (terselesaikan) }\end{array}$ & 3,4 & 85 & Sangat Baik \\
$\begin{array}{l}\text { Panduan aplikasi jelas dan } \\
\text { mudah dipahami }\end{array}$ & 3,7 & 93 & Sangat Baik \\
\hline Keseluruhan indikator & $\mathbf{3 , 5}$ & $\mathbf{8 8}$ & Sangat Baik \\
\hline
\end{tabular}

Tabel 3 terlihat seluruh poin dalam penilaian aspek penggunaan memiliki predikat sangat baik dimana rata-rata penilaian 3,5 dengan presentase $88 \%$ sehingga dalam aspek tampilan 
dapat disimpulkan bahwa aplikasi kmois sangat baik dan dapat digunakan dalam masyarakat.

\section{Kajian Produk Akhir}

Setelah melaluai tahap ujicoba blackbox, validasi dan ujicoba pengguna kelompok besar maka Gambar 1 merupakan hasil produk akhir aplikasi kmois berbasis android.
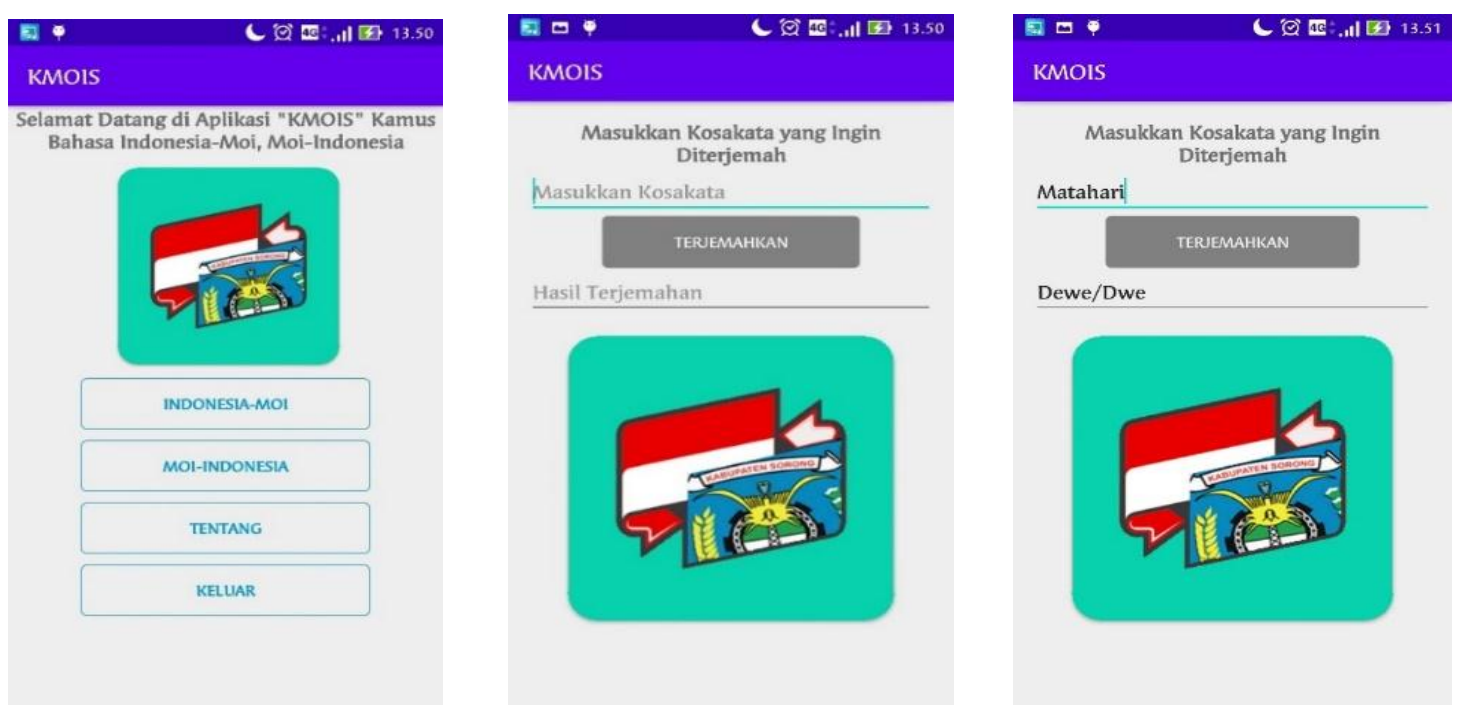

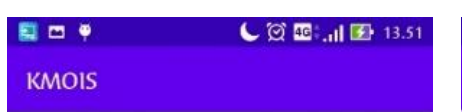

Masukkan Kosakata Moi yang Akan Diterjemahkan Kedalam Bahaa Indonesia Masukkan Kosakata

\section{TERUEMAHKAN}

\section{Hasil Terjemahan}

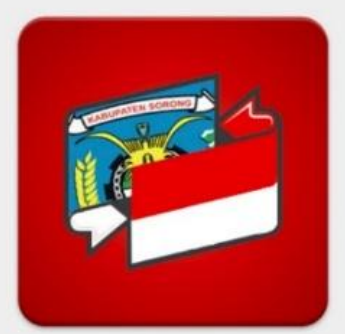

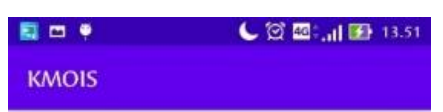

Masukkan Kosakata Moi yang Akan Diterjemahkan Kedalam Bahaa Indonesia Leim

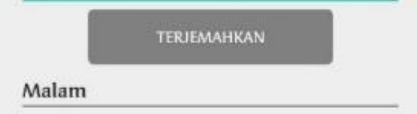

Malam

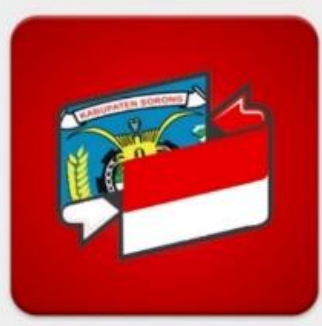

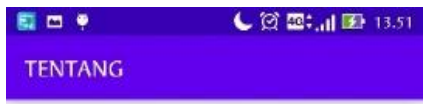

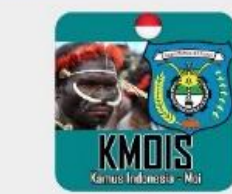

KMOIS merupakan kamus bahas: ndonessia-Moi dan Moi-Indonesia. Dalam kosakata dari Indonesia ke bahasa Moi dan sebaliknya. Aplikasl ini di buat dengar cujuan melestarikan bahasa Mol yan Papua Barat serta sebagai medi pembelajaran bahasa Moi terutama bag masyarakat pendatang yang ingin Reverensi Kamus Indonesia-Mol: 1. Dr. Stepanus Malak, M.St. 2. Dr. Wa Ode Likewati, SE, MM 3. Ketua LMA Malatnd

Version 1.0 .0 Copyright @ 2020 Trio Nurdianto | Universitas Pendidilikan

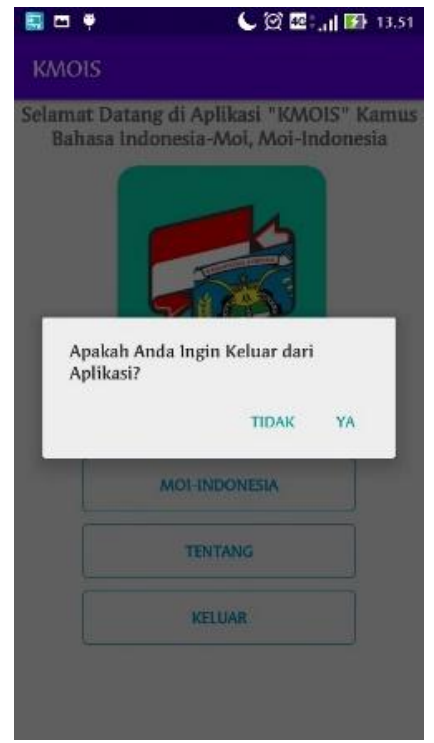

Gambar 1. Hasil Produk Akhir 


\section{Kesimpulan}

Berdasarkan hasil penelitian rancang bangun aplikasi kmois berbasis android dengan menggunakan android studio dan database sqlite dapat disimpulkan bahwa aplikasi kmois yang telah dibuat dapat berjalan dengan baik. Aplikasi yang telah selesai dibuat mendapat penilaian oleh pegguna dengan hasil yang cukup baik. Dalam pengujian ujicoba yang dilakukan kepada 31 pengguna, aplikasi kmois memiliki penilaian dengan presentase $84 \%$ untuk aspek tampilan dan $88 \%$ untuk aspek penggunaan. Aplikasi kmois juga telah memiliki cara penggunaan yang mudah di gunakan oleh pengguna yang tersedia dalam menu bantuan aplikasi serta video tutorial yang tersedia di youtube. dengan hasil yang telah dicapai maka aplikasi kmois telah memenuhi harapan dan dapat digunakan sebagaimana mestinya.

\section{Daftar Pustaka}

Devdas, R. (2011) 'Prototyping Model', pp. 1-6. Available at: https://www.sdlc.ws/prototyping-model/.

Haris, L. E. and Pardiansyah, A. S. (2018) 'Aplikasi Android Kamus Bahasa IndonesiaSasak', Jurnal Manajemen Informatika dan Sistem Informasi, 1(1), p. 1. doi: 10.36595/misi.v1i1.10.

Haviluddin (2011) 'Memahami Penggunaan UML ( Unified Modelling Language )', Memahami Penggunaan UML (Unified Modelling Language), 6(1), pp. 1-15. Available at: https://informatikamulawarman.files.wordpress.com/2011/10/01-jurnal-informatikamulawarman-feb-2011.pdf.

Kasema, L. O. et al. (2018) 'Aplikasi Kamus Bahasa Daerah Pasan Berbasis Android', 13(2), pp. 1-6.

Kusniyati, H. and Pangondian Sitanggang, N. S. (2016) 'Aplikasi Edukasi Budaya Toba Samosir Berbasis Android', Jurnal Teknik Informatika, 9(1), pp. 9-18. doi: 10.15408/jti.v9i1.5573.

M. Komarudin (2016) 'Pengujian perangkat Lunak metode Black box berbasis partitions pada aplikasi sistem informasi di sekolah', jurnal Mikrotik, o6(3), pp. 02-16. doi: http://dx.doi.org/10.1016/j.brat.2012.09.004.

Rachmawati, A., Nugraha, A. and Awaluddin, M. (2017) 'Desain Aplikasi Mobile Informasi Pemetaan Jalur Batik Solo Trans Berbasis Android Menggunakan Location Based Service', Jurnal Geodesi Undip, 6(2), pp. 46-55.

SAPUTRA, I. A. (2017) 'Aplikasi Layanan Bengkel Mobil Berbasis Android Di Kota Bandar Lampung', Journal of Chemical Information and Modeling, 53(9). doi: 10.1017/CBO9781107415324.004.

Shiddiq, I. F. and Witanti, A. (no date) 'Aplikasi Kamus Bahasa Jawa Ngoko , Jawa Krama, dan Indonesia Berbasis Android Dengan Menggunakan Metode Sequential Search Application of Javanese Ngoko , Javanese Krama, and Android-based Indonesian Dictionary Using Sequential Search Method', pp. 21-28.

Sofya, N. D., Esabella, S. and -, R. (2017) 'Rancang Bangun Aplikasi Kamus Bahasa Sumbawa Berbasis Android', Jurnal Matrik, 17(1), p. 36. doi: 10.30812/matrik.v17i1.59. 
Suaib, H. and Fitrianto, A. (2015) 'A Study of Economic Empowerment of Moi Tribe in Sorong, West Papua', International Journal of Asian Social Science. doi: 10.18488/journal.1/2015.5.12/1.12.694.705.

Suendri (2018) 'Implementasi Diagram UML (Unified Modelling Language) Pada Perancangan Sistem Informasi Remunerasi Dosen Dengan Database Oracle (Studi Kasus: UIN Sumatera Utara Medan)', Jurnal Ilmu Komputer dan Informatika, 3(1), pp. 1-9.

Sutejo, S. (2016) 'Pemodelan UML Sistem Informasi Geografis Pasar Tradisional Kota Pekanbaru', Digital Zone: Jurnal Teknologi Informasi dan Komunikasi, 7(2), pp. 89-99. doi: 10.31849/digitalzone.v7i2.600.

Wati, R. and Ernawati, S. (2018) 'Perancangan Aplikasi Kamus Bahasa Jawa-Indonesia Berbasis Android', Jurnal Techno Nusa Mandiri, 15(2), p. 93. doi: 10.33480/techno.v15i2.893.

Winarni, E. W. (2018) Teori Dan Praktik Penelitian Kuantitatif Kualitatif Penelitian Tindakan Kelas (PTK) Research And Development (R\&D). Edited by R. A. Kusumaningtyas. Bumi Aksara. 